\title{
Coal waste slurries as a fuel for integrated gasification combined cycle plants
}

\author{
Marcin A. Lutynski ${ }^{1, a}$, and Aleksander Lutynski ${ }^{2}$ \\ ${ }^{1}$ Silesian University of Technology, Faculty of Mining and Geology, ul. Akademicka 2, 44-100 Gliwice, Poland \\ ${ }^{2}$ KOMAG Institute of Mining Technology, Pszczynska 37, 44-101 Gliwice, Poland
}

\begin{abstract}
The article summarizes recent development in integrated gasification combined cycle technology and lists existing and planned IGCC plants. A brief outlook on the IGCC gasification technology is given with focus on entrained-flow gasifiers where the low-quality coal waste slurry fuel can be used. Desired properties of coal and ash for entrained-flow gasifiers are listed. The coal waste slurries, which were deposited at impoundments in Upper Silesian Coal Basin, were considered as a direct feed for such gasifiers. The average ash content, moisture content and lower heating value were analysed and presented as an average values. Entrained-flow commercial gasifiers can be considered as suitable for the coal slurry feed, however the ash content of coal slurries deposited in impoundments is too high for the direct use as the feed for the gasifiers. The moisture content of slurries calculated on as received basis meets the requirements of entrained-flow slurry feed gasifiers. The content of fines is relatively high which allow to use the slurries in entrained-flow gasifiers.
\end{abstract}

\section{Introduction}

Integrated gasification combined cycle (IGCC) is a promising clean coal technology which has been successfully implemented in several operational, commercial scale and other semi-industrial scale plants (Table 1) [1,2]. The majority of the plants is fuelled by coal although the main advantage of the IGCC plant is its fuel flexibility. For the IGCC technology to become more competitive and fully commercial, low availability (defined as plant operation time during a certain period of time, usually 1 year) and high capital costs are the main challenges [3]. In general, the cycle in a typical IGCC plant consists of two main stages. Firstly, the fuel is converted to syngas, which is a mixture of hydrogen and carbon monoxide. Secondly, the syngas is converted to electricity in a combined cycle power block consisting of a gas turbine process and a steam turbine process which includes a heat recovery steam generator (HRSG). In fact, the combined cycle technology is similar to the technology used in modern natural gas fired power plants. The IGCC plants have several advantages over either typical PC plants or fluidized bed power plants. The advantages are with lower production of solid waste, fuel flexibility or low $\mathrm{NO}_{\mathrm{x}}$ and $\mathrm{SO}_{\mathrm{x}}$ emission.

\footnotetext{
${ }^{a}$ Corresponding author: marcin.lutynski@polsl.pl
} 
Table 1. Existing and planned IGCC plants (after [2]).

\begin{tabular}{|c|c|c|}
\hline $\begin{array}{c}\text { Plant (location) initial year of } \\
\text { operation }\end{array}$ & Size (MW) & Feedstock \\
\hline Buggenum (Netherlands) 1994 & 253 & Coal \& biomass \\
\hline Wabash river (USA) 1995 & 262 & Bituminous coal \& petroleum coke \\
\hline Tampa (USA) 1996 & 250 & Coal \& petroleum coke \\
\hline Pernis (Netherlands) 1997 & 155 & Heavy fuel oil, tar \\
\hline Priolo Gargallo (Italy) 1998 & 532 & Petroleum coke \\
\hline Puertollano (Spain) 1998 & 335 & Residual oil, tar, bitumen \\
\hline Sarlux (Italy) 2000 & 548 & Heavy oil, asphalt \\
\hline Negishi (Japan) 2003 & 342 & Brown coal \\
\hline Vresova (Czech Republic) 2005 & 400 & Mid-western coal \\
\hline Knox County (USA) 2013 & 618 & Lignite coal \\
\hline Kemper County (USA) 2014 & 582 & Bituminous \\
\hline Nakoso (Japan) 2014 & $500-600$ & \\
\hline
\end{tabular}

As the IGCC technology requires low quality fuel, it is anticipated that coal slurries resulting from the coal beneficiation process can be of great importance as the potential low cost feedstock for the gasification process. In this study, the coal waste slurries resulting from the coal beneficiation process of Polish coal mines were considered as a potential fuel for commercially available IGCC plants.

\section{Integrated gasification combined cycle gasifiers overview and fuel requirements}

\subsection{Gasifier type}

There are three common types of gasifiers used in commercially available IGCC systems: fixed-bed, fluidized bed and entrained flow. There is also one technology called the Molten-bath witch is capable of gasification both coking and non-coking coals but its development is not yet advanced enough to be considered in this study. One of the factors for selection of gasifier is the fuel type. In the fixed-bed and fluidized bed gasifiers the fuel (coal) should have low moisture content of $<18 \%$ [4]. The entrained-flow gasifiers are the most common commercial gasifiers due their high throughput, when compared to the other technologies currently available in the market. Therefore, only the entrainedflow gasifiers could be suitable for coal waste slurries gasification (Fig. 1).

In general, there are five commercially available entrained-flow gasifier. In Table 2, a short summary of commercially available entrained-flow gasifiers is presented. 

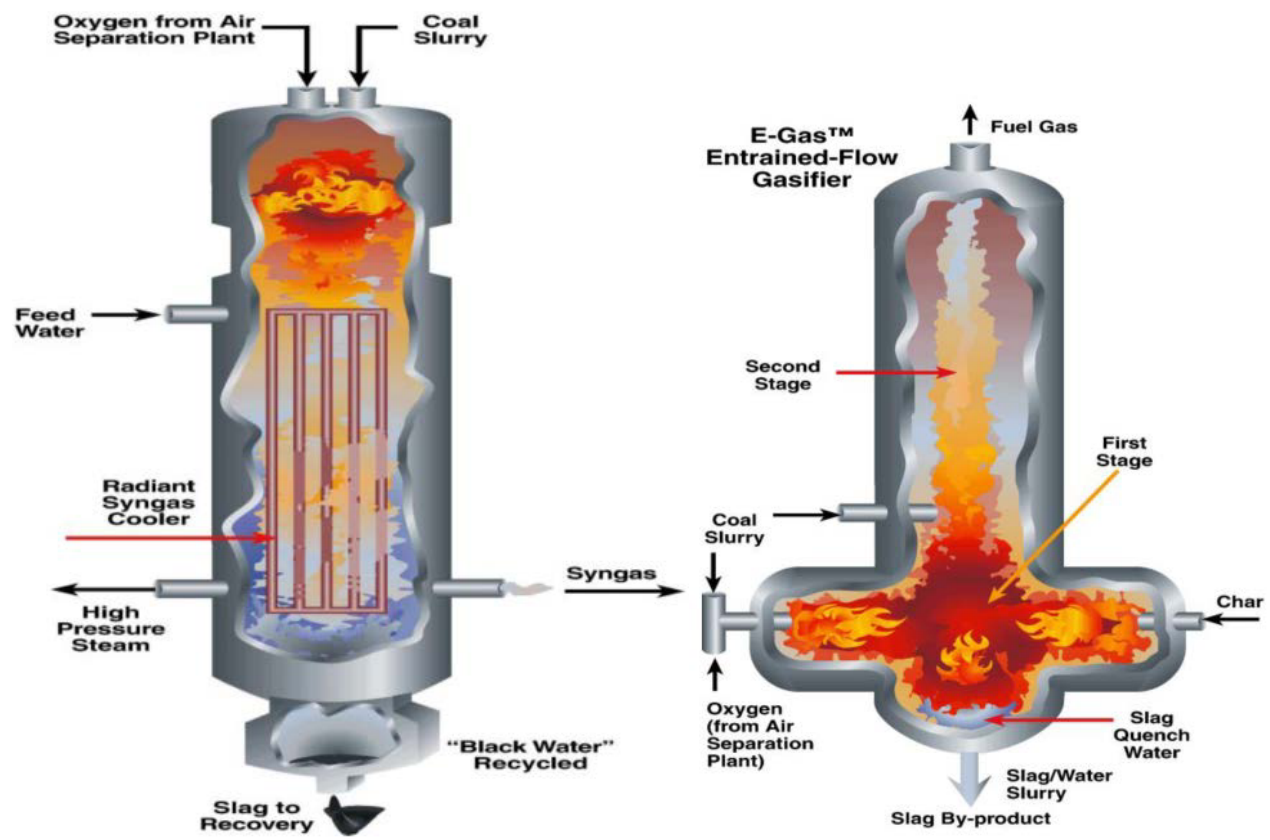

Figure 1. Examples of entrained-flow slurry feed gasifiers. GE Energy Gasifier with Radiant cooling (left) and Conoco Phillips E-gas gasifier [5].

Table 2. Characteristics and features of commercially available entrained-flow gasifiers (after [6]).

\begin{tabular}{|c|c|c|c|c|c|}
\hline $\begin{array}{c}\text { Gasification } \\
\text { Technology/ } \\
\text { Design feature }\end{array}$ & $\begin{array}{l}\text { Ge energy } \\
\text { with } \\
\text { Radiant } \\
\text { Cooling }\end{array}$ & $\begin{array}{c}\text { Ge energy } \\
\text { with Water } \\
\text { Quench }\end{array}$ & Shell Scgf & $\begin{array}{c}\text { Conocophillips } \\
\text { E-gas }\end{array}$ & Siemens Sfg \\
\hline Feed system & $\begin{array}{c}60 \%-70 \% \\
\text { coal } / \text { water } \\
\text { slurry; top } \\
\text { feed }\end{array}$ & $\begin{array}{c}60 \%-70 \% \\
\text { coal } / \text { water } \\
\text { slurry; top } \\
\text { feed }\end{array}$ & $\begin{array}{c}\text { Dry coal } \\
(\sim 2 \% \\
\text { moisture } \\
\text { content }) / \mathrm{N}_{2} ; \\
\text { bottom feed }\end{array}$ & $\begin{array}{c}60 \text { to } 70 \% \\
\text { coal/water } \\
\text { slurry; bottom } \\
\text { feed: } 1 \text { st stage } \\
80 \% \text { and } 2 \text { nd } \\
\text { stage } 20 \%\end{array}$ & $\begin{array}{l}\text { Dry feed/ } \mathrm{N}_{2} \text { or } \\
\mathrm{CO}_{2} \text {; top feed }\end{array}$ \\
\hline Wall & Refractory & Refractory & Membrane & Refractory & $\begin{array}{c}\text { Cooling screen } \\
\text { (ash content }> \\
1-2 \mathrm{wt} \% \text { ) }\end{array}$ \\
\hline Pressure (bar) & $30-80$ & $30-80$ & $30-40$ & $2 \sim 27$ & $\geq 40$ \\
\hline $\begin{array}{c}\text { Hot syngas } \\
\text { temperature }\left({ }^{\circ} \mathrm{C}\right)\end{array}$ & $1260-1500$ & $1260-1500$ & $1360-1650$ & $\begin{array}{c}\text { 1st stage } 1340- \\
1400 ; 2 \text { nd stage } \\
1038\end{array}$ & $1400-1600$ \\
\hline $\begin{array}{l}\text { Syngas quenching } \\
\text { method }\end{array}$ & $\begin{array}{l}\text { Radiant } \\
\text { cooling then } \\
\text { fire tube } \\
\text { syngas } \\
\text { cooler } \\
\end{array}$ & $\begin{array}{l}\text { Water quench } \\
\text { (no syngas } \\
\text { cooler) }\end{array}$ & $\begin{array}{l}\text { Recirculated } \\
\text { cold syngas } \\
\text { quench then } \\
\text { water tube } \\
\text { syngas cooler }\end{array}$ & $\begin{array}{l}\text { Chemical } \\
\text { quench then } \\
\text { fire tube syngas } \\
\text { cooler }\end{array}$ & $\begin{array}{l}\text { Water quench } \\
\text { (no syngas } \\
\text { cooler) }\end{array}$ \\
\hline $\begin{array}{l}\text { Quenched syngas } \\
\text { temperature }\left({ }^{\circ} \mathrm{C}\right)\end{array}$ & $\sim 800$ & $\sim 300$ & $\sim 900$ & $\sim 1038$ & $\sim 230$ \\
\hline
\end{tabular}




\subsection{Desired coal and ash properties}

The increased moisture content requires more energy to vaporize the water, while the and increased ash content means a greater mass flow of inerts which must be heated up. Therefore, both the increased moisture and ash content have the effect of higher oxygen consumption and lower cold gas efficiency.

The dry feed gasifiers, the coal is dried before gasification so that the gasifier does not have to process the extra steam from coals with the high moisture content. Obviously, drying of coal to around $2 \%$ of moisture consumes a part of the energy from the produced syngas. The slurries of coal with high moisture content achieve lower solids concentration, and therefore a large amount of steam must be vaporized, and then processed in the gasifier. This contributes to reduction of the capacity per gasifier volume because the residence time per unit volume is reduced [3].

The ash content is an important criteria for selection the gasifier. In general, the ash content for slurry feed should not exceed $20 \%$, whereas for the dry feed $40 \%$. The feed particle size in the entrained flow gasifiers should not exceed $100 \mu \mathrm{m}$ for dry feed and $1000 \mu \mathrm{m}$ for the slurry feed.

Other criteria for coal and ash properties for the entrained-flow gasifiers are summarized in Table 3. In particular, the ash properties are of great importance in the gasification process. The mineral matter and/or inorganic components may vaporize, form either liquids or solids. Formation of three phase products is a significant difference in the coal burning process. The major problem in the process of gasification is condensation of inorganic compounds which may result in slagging. The slag is formed when the ash particles deposit on the gasifier wall and flow down as highly vitreous product. To some extent the slagging effect is desirable in the entrained-flow gasifiers since a small slag layer on the refractory is desirable, as this layer protects the refractory lining and reduces heat loss. However, at high temperature and reduced viscosity, the molten slag layer can be very corrosive and can penetrate into the air-cooled refractory lining, the desired properties of coal and ash for entrained-flow gasifiers are summarized in Table 3.

Table 3. Summary of criteria for ash and coal properties for entrained-flow gasifiers $[4,6]$.

\begin{tabular}{|c|c|}
\hline Coal and ash properties & Criteria for entrained-flow gasifier \\
\hline Coal rank & Any (dry feed); High (Slurry feed) \\
\hline Acceptability of fines & Unlimited \\
\hline Ash contents & $20 \%$ slurry feeding, $40 \%$ dry feeding \\
\hline Ash Temperature & $\begin{array}{c}\text { (FT) }<1400{ }^{\circ} \mathrm{C} \text { is optimal, but } 1500{ }^{\circ} \mathrm{C} \text { is acceptable; }>1500{ }^{\circ} \mathrm{C} \text { flux is } \\
\text { needed }\end{array}$ \\
\hline Ash composition & $\begin{array}{c}\text { silica ratio } 100 \mathrm{SiO}_{2} /\left(\mathrm{SiO}_{2}+\mathrm{Fe}_{2} \mathrm{O}_{3}+\mathrm{CaO}+\mathrm{MgO}\right)<80 \\
\mathrm{SiO}_{2} / \mathrm{Al}_{2} \mathrm{O}_{3} \text { ratio of } 1.6-2.0 \text { is optimal for minimum flux amount }\end{array}$ \\
\hline Temperature of critical viscosity (Tcv) & $<1400{ }^{\circ} \mathrm{C}$ is preferred \\
\hline Viscosity & 5-25 Pa.s at 1400 to $1500{ }^{\circ} \mathrm{C}$; Optimum $15 \mathrm{~Pa} \cdot \mathrm{s}$ \\
\hline
\end{tabular}

\section{Analyses of coal waste slurries properties}

Since the IGCC technology, particularly entrained-flow gasifiers, required low quality fuel as the feedstock and the feed can be in the form of a slurry, it was decided to assess coal slurries deposited in impoundments as a potential fuel. The impoundments were filled with the slurries resulting from the process of steam and coking coal beneficiation in Polish coal mines. The small size gangue was difficult to remove using conventional beneficiation methods such as froth flotation. The presence of fines was significantly lowering the quality of coke. Therefore, particles smaller than $1 \mathrm{~mm}$ were considered as a waste. The same situation was observed in the case of steam coal as it was impossible 
to burn small particles in stoker-fired boilers. Due to that fact, the coal slurry was stored on the surface in either impoundments or ponds.

Impoundments are located in the Upper Silesia Coal Basin (Southern Poland) where currently over 30 coal mines are in operation. Formerly, over 100 mines were active, hence the large number of abandoned impoundments could be potentially used as a fuel either directly or after processing. Investigation of coal slurries properties was performed within the framework of development project entitled No N R09 0006 06/2009 "Identification of energetic potential of coal slurries in the national fuel balance and technological development strategy of their usage" [7].

For the purpose of this study the following properties of coal slurries were analysed (on as received basis):

- $\quad$ ash content

- moisture content

- $\quad$ content of fine fraction $(<0.1 \mathrm{~mm})$

- lower heating value (LHV).

The properties of coal slurries deposited in 20 impoundments on the as received basis were averaged and are presented in Table 4. Large variations in the properties of coal slurries reflected in the calculated standard deviation for each property.

Table 4. Properties of coal waste slurries considered for the use in IGCC technologies (as received basis).

\begin{tabular}{|c|c|c|}
\hline Property & Average & Standard deviation \\
\hline Ash content, $\%$ & 34.2 & 10.1 \\
\hline Moisture content, $\%$ & 25.6 & 5.7 \\
\hline Content of fine fraction $(<0.1 \mathrm{~mm}), \%$ & 62.3 & 14.3 \\
\hline Lower Heating Value, $\mathrm{MJ} / \mathrm{kg}$ & 13.1 & 3.7 \\
\hline
\end{tabular}

Since the analyses of properties was done on "as received" basis and this state is relevant to the case where slurry feed gasifier is used it was decided to analyse the properties on air dried basis which would be more relevant to dry feed gasifiers. The results of analysis based on air dried basis are shown in Table 5.

Table 5. Properties of coal waste slurries considered for the use in IGCC technologies ("air dried" basis).

\begin{tabular}{|c|c|c|}
\hline Property & Average & Standard deviation \\
\hline Ash content, $\%$ & 42.6 & 12.3 \\
\hline Moisture content (air dried), \% & 2.9 & 2.1 \\
\hline Lower Heating Value, MJ/kg & 16.4 & 4.5 \\
\hline
\end{tabular}

\section{Discussion}

Results presented in Tables 4 and 5 show that the average ash content for both "as received" and "air dried" basis are over the requirements of the entrained-flow gasifiers. Although the water content (moisture) is sufficient (on average 25.6\%) to consider the coal slurry as the direct feed for the gasifier, the ash content is significantly too high (above required 20\%). If the slurry would be dried to "air dried" state the moisture content would be in average $2.9 \%$, which is still over the required $2 \%$ for the dry feed gasifiers.

The lower heating values of coal slurries was on average $13.1 \mathrm{MJ} / \mathrm{kg}$ for "as received" slurries and 16.4 $\mathrm{MJ} / \mathrm{kg}$ for dried slurries. Experience with commercial gasifiers show that best results were obtained for LHV values ranging between $20-30 \mathrm{MJ} / \mathrm{kg}[8,9]$. Therefore, coal slurries cannot be 
considered as the direct feed for the gasifiers. However, there is a possibility to upgrade coal slurries with commonly known methods such as either gravity separation or flotation [10].

The only parameter, which would allow to use the slurries in IGCC gasifiers, is the content of fines $(<0.1 \mathrm{~mm})$ which on average is above $62.3 \%$. Only in two impoundments the content of fines was below $30 \%$, whereas in the rest it was higher tan $60 \%$. The high content of fines makes this feed much easier to process since it does not require comminution.

Other important issue regarding the use of coal waste slurries for IGCC gasifiers is the ash (slag) composition. In this research this issue was not considered although will be taken into account in further studies.

\section{Conclusions}

The study was a first attempt to assess if the coal waste slurries deposited in impoundments could serve a direct feed for IGCC gasifiers. The following conclusions can be drawn from the study:

- entrained-flow commercial gasifiers can be considered as suitable for the coal slurry feed,

- the ash content of coal slurries deposited in impoundments in the Upper Silesia Coal Basin is too high for the direct use as the feed for the gasifiers,

- the lower heating value of coal slurries is relatively low in comparison to coal used in pilottests,

- the moisture content of slurries calculated on the as received basis meet the requirements of entrained-flow slurry feed gasifiers,

- the content of fines is relatively high, which allows the use of slurries in entrained-flow gasifiers.

One of the most important properties of the fuel for IGCC entrained-flow gasifiers is the ash composition which was not analysed in this study. Further studies focused on this should be carried out to verify if such low quality fuel can be considered for the use in IGCC technology.

\section{References}

1. J. Tollefson, R. Van Noorden, Nature, 484, 151 (2012)

2. M. Hossein Sahraei, D. McCalden, R. Hughes, L.A. Ricardez-Sandoval, Fuel 137, 245 (2014)

3. O. Maurstad. An Overview of Coal based Integrated Gasification Combined Cycle (IGCC) Technology (MIT 2005)

4. V. Krishnamoorthy, S.V. Pisupati, Energies, 8, 104 (2015)

5. R.W. Breault, Energies, 3, 216 (2010)

6. P. Wang, M. Massoudi, Energies, 6, 784 (2013)

7. Report on Identification of energetic potential of coal slurries in the national fuel balance and technological development strategy of their usage, (Silesian University of Technology, 2009)

8. L. Zheng, E. Furinsky, Energy Convers. Manage. 46, 1767 (2005)

9. Tampa Electric Polk Power Station Integrated Gasification Combined Cycle Project: Final Technical Report, (US DOE, Tampa, Florida, 2002)

10. J. Szpyrka, M. Lutynski, Physicochem. Probl. Miner. Process. 48, 579 (2012) 